\title{
Paleoseismological data from a new trench across the EI Camp Fault (Catalan Coastal Ranges, NE Iberian Peninsula)
}

\author{
Hector Perea $\left({ }^{1}\right)$, Paula M. Figueiredo $\left({ }^{2}\right)\left({ }^{3}\right)$, Jesús Carner $\left({ }^{1}\right)$, Stefano Gambini $\left({ }^{4}\right)$, Kirsty Boydell $\left({ }^{5}\right)\left({ }^{1}\right)$ \\ Departamento Geodinàmica i Geofísica, Universitat Barcelona, Spain \\ ( $\left.{ }^{2}\right)$ LATTEX, Laboratório de Tectonofísica e Tectónica Experimental, \\ Faculdade de Ciências da Universidade de Lisboa, Portugal \\ $\left({ }^{3}\right)$ ICTE, Instituto de Ciências da Terra e do Espaço, Universidade de Lisboa, Portugal \\ ${ }^{4}{ }^{4}$ School of Earth Sciences, The University of Leeds, U.K. \\ ${ }^{5}$ ) Department of Civil and Environmental Engineering, London, U.K. \\ and participants in the Europaleos course \\ Paola Albini, Pedro Alfaro, Raquel Amores, Ramon Arrowsmith, Kuvvet Atakan, Milos Bavec, \\ Kelvin Berryman, Tamer Yigit Duman, Khalilallah Feghhi, Matthieu Ferry, Alessandro Fontana, \\ Chrysa Gountromichou, Robert Hus, Juan Miguel Insua, Ramon Julià, Fidel Martín, Eulàlia Masana, \\ Mustapha Meghraoui, Vasso Mouslopoulou, Bruno Pace, Niko Palyvos, Daniela Pantosti, Gwendolyn Peters, \\ Stefano Pucci, Alexander Radulov, José Sánchez-Cabañero, Pere Santanach, Gordon Seitz, \\ Yonathan Shaked, Dimitra Tsoukala and Gulsen Ucarkus
}

\begin{abstract}
The El Camp Fault (Catalan Coastal Ranges, NE Iberian Peninsula) is a slow slipping normal fault whose seismic potential has only recently been recognised. New geomorphic and trench investigations were carried out during a training course across the El Camp Fault at the La Porquerola alluvial fan site. A new trench (trench 8) was dug close to a trench made previously at this site (trench 4). With the aid of two long topographic profiles across the fault scarp we obtained a vertical slip rate ranging between 0.05 and $0.08 \mathrm{~mm} / \mathrm{yr}$. At the trench site, two main faults, which can be correlated between trenches 8 and 4, make up the fault zone. Using trench analysis three paleoseismic events were identified, two between 34000 and 125000 years BP (events 3 and 2) and another event younger than 13500 years BP (event 1), which can be correlated, respectively, with events $X$ (50000125000 years BP), $Y$ (35000-50000 years BP) and $Z$ (3000-25000 years BP). The last seismic event at the La Porquerola alluvial fan site is described for the first time, but with some uncertainties.
\end{abstract}

Key words paleoseismicity - trenching - normal faultCatalan Coastal Ranges - El Camp Fault

Mailing address: Dr. Hector Perea, Universitat Barcelona, Departamento Geodinàmica i Geofísica, Zona Universitària de Pedralbes, Barcelona 08028, Spain; e-mail: hector@geo.ub.es

\section{Introduction}

Paleoseismologic methods developed in high seismicity areas for high slip rate faults are increasingly used for improving the calculations of seismic hazard on faults with very low slip rates $(<0.1 \mathrm{~mm} / \mathrm{yr})$. This is the case of some fault systems in Europe, such as the Rhine 
Graben, the Catalan Coastal Ranges and the Betic Cordillera. In fact, the recognition of the seismogenic characteristics of a fault, i.e. the evaluation of its slip rate, the size of the maximum expected earthquake and the age of the most recent surface faulting earthquake can substantially change the perception of seismic hazard in regions traditionally considered to be stable or not very active.

The «Europaleos field training course in paleoseismology» focused on the El Camp Fault (Catalan Coastal Ranges, NE Iberian Peninsula) and was held in Cambrils (Spain) in February 2001. The aim of this course was to provide training for young researchers in paleoseismology. The course centred on the El Camp Fault for the following reasons: a) earlier studies have demonstrated its potential for paleoseismic investigation; b) some uncertainties concerning the fault geometry and its seismic behaviour remained to be resolved; c) it is a good example of a low slip rate fault that could be encountered in other parts of Europe and around the Mediterranean, and d) the area is characterised by high seismic vulnerability. This paper seeks to gain an insight into the slip rate and paleoseimic history of the fault, account for change in the scarp direction visible at the trench site and to present the results obtained during the Europaleos course.

\section{The El Camp Fault}

The El Camp Fault is located on the southeastern flank of the Catalan Coastal Ranges (fig. 1) which are bounded by the València trough basin on the west. The Catalan Coastal Ranges are characterised by an en échelon array of NE-SW faults, where the main faults are listric, dip to the SE and have the detachment level at a depth of $15 \mathrm{~km}$ (Roca and Guimerà, 1992; Roca, 1996). The Catalan Coastal Ranges are the result of an E-W extension, which affected the eastern part of the Iberian Peninsula during the Neogene (Mauffret et al., 1973; Fontboté et al., 1990; Banda and Santanach, 1992; Roca and Guimerà, 1992; Roca, 1996). This extension has been interpreted as a product of an extensional back-arc basin related to the

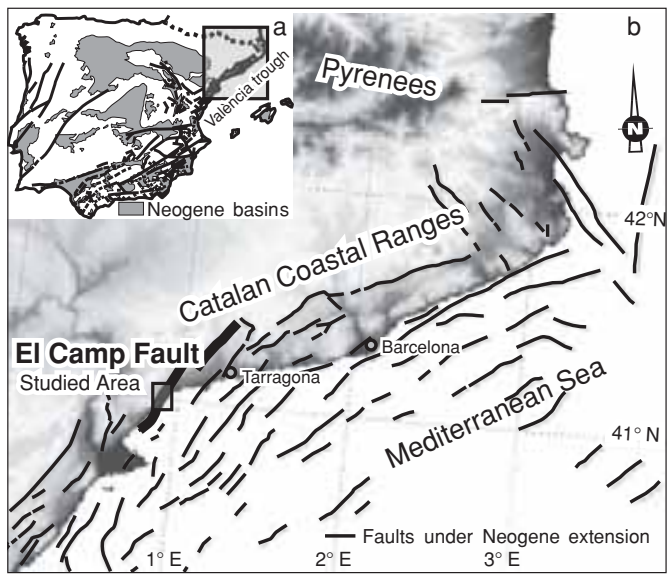

Fig. 1. Location maps: $a$ ) location of the Catalan Coastal Ranges within the Iberian Peninsula. The map shows the Neogene basins and the faults with Neogene extension; $b$ ) Location of the El Camp Fault within the Catalan Coastal Ranges. The map shows the en échelon array of NW-SE Neogene listric faults in the Catalan Coastal Ranges.

Apennine subduction (Doglioni et al., 1997, 1999; Gueguen et al., 1998). Earlier studies on the Catalan Coastal Ranges suggest that these ranges have been in a post-rift stage with weak tectonic activity since the middle Miocene (Roca and Guimerà, 1992; Roca, 1996).

The El Camp Fault is made up of two en échelon faults (north and south segments). From commercial and deep seismic profiles, it has been shown that the El Camp Fault is a normal fault, with a dip of $60^{\circ}$ and the main detachment level located at 13-15 km depth (Roca, 1992; Roca and Guimerà, 1992; Sàbat et al., 1997). The El Camp Fault constitutes the north-western limit of the El Camp basin. Near the town of Reus, the detrital sedimentary infill of the El Camp basin has a thickness of 1400-2000 m, which extends from the Miocene to the present time (Nuñez et al., 1980; Medialdea et al., 1986).

The El Camp Fault has not shown significant historical or instrumental seismic activity. However, recent paleoseismologic studies based on detailed geomorphological and trench analyses have shown that the El Camp Fault is active, particularly its southern segment. This 
segment is approximately $24 \mathrm{~km}$ long, bearing in mind that the fault extends under the sea for a distance of $10 \mathrm{~km}$. The segment is characterised by: a) a slip rate ranging between 0.02 and $0.08 \mathrm{~mm} / \mathrm{yr}$; b) surface faulting earthquakes of $M_{w}=6.7$ maximum magnitude; c) an average recurrence interval of 30000 years, and d) the occurrence of the last event 3000 years ago (Masana, 1995, 1996; Masana et al., 2000, 2001a,b; Santanach et al., 2001). Seven trenches located at different sites in the southern segment of the El Camp Fault enabled these authors to describe three seismic events during the last 125000 years: event $X$, event $Y$ and event $Z$. Event $X$, between 125000 and 50000 years BP, has been clearly described at two sites (site of trenches 1 and 2 and site of trench 4). Event $Y$, between 50000 and 35000 years BP, has only been described at the site of trench 4 . Event Z, between 25000 and 3000 years BP, has been described at two sites (at trenches 1 and 2 - strongly based - and at trench 3 ).

\section{Geomorphologic and topographic survey}

The geological and geomorphological study of the southern part of the El Camp basin (fig. 2) reveals the presence of recent alluvial fans of four generations: G1, G2, G3 and G4 (Villamarín et al., 1999; Santanach et al., 2001), which were mapped and surveyed in the field during Europaleos. Fans belonging to the G2 and G3 generations stretch from the mountain range to the sea, whereas those corresponding to the G4 generation are located at the foot of the mountain range or in the lowlands between the fans of the older generations. According to different dating methods (U/Th, thermoluminescence, paleomagnetic studies and correlation between different fan generations and sea level highstands), minimum ages of 300000 and 125000 years have been attributed to the top of the G2 and G3 generations, respectively (Villamarín et al., 1999; Santanach et al., 2001), the G4 generation being younger than 125000 years in age. The oldest fans belonging to the G1 generation were not considered in this study since they do not interact with the fault where it is exposed.

The geomorphological map (fig. 2) shows a discontinuous fault scarp offsetting alluvial fans belonging to the G2, G3 and G4 generations. The El Camp Fault scarp offsets the G4 generation fans between the La Porquerola and the Les Planes fans and south of the Les Planes fan. These observations indicate that this segment of the fault has been active during the last 125000 years. For logistical reasons, we focused on one portion of the La Porquerola fan, where the fault affects the top of the G3 generation fan. This fan is highly cemented and therefore difficult to erode in contrast to the unconsolidated materials in the lower part of the scarp. Consequently, the scarp is clearly visible at the surface and a change in the direction is recognisable. The scarp is the result of a normal fault-propagation fold with a small scarplet at the bottom. Locally, a small wall constructed along the foot of the scarp operates as a sediment trap and has produced some sharp morphologies that are visible on the trench walls. To the NE of trench 4 , the scarp shows a change in direction close to a gully that is entrenched in the scarp.

Using a total station (Leica 1700), we made a microtopographic map of the selected area (fig. 3 ) and five topographic profiles. This information together with the geomorphology helped us to select the most favourable site for trenching. We decided to dig the trench in the zone where the fault scarp changes its direction (fig. 3) in an attempt to determine whether the change in the scarp direction was due to a change in the fault direction or to erosion evidenced by the small gully located there. In addition, the location of the new trench in the vicinity of the gully would enable us to obtain a more complete section of recent sediments on the downthrown wall than at trench 4 . Thus, the possibility of detecting the most recent paleoseismic event, which had not been observed at this site, is greater.

Only two topographic profiles (fig. 4) were long enough to obtain a preliminary evaluation of the slip rate at this location. The offset of the 125000 years fan surface measured in the profiles is between 6.7 and $10.5 \mathrm{~m}$. This provides a maximum vertical slip rate between 0.05 and $0.08 \mathrm{~mm} / \mathrm{yr}$. Although these results are consistent with the slip rates obtained in earlier studies on the El Camp Fault, which vary from 0.02 to $0.08 \mathrm{~mm} / \mathrm{yr}$ (Masana, 1995, 1996; Masana 


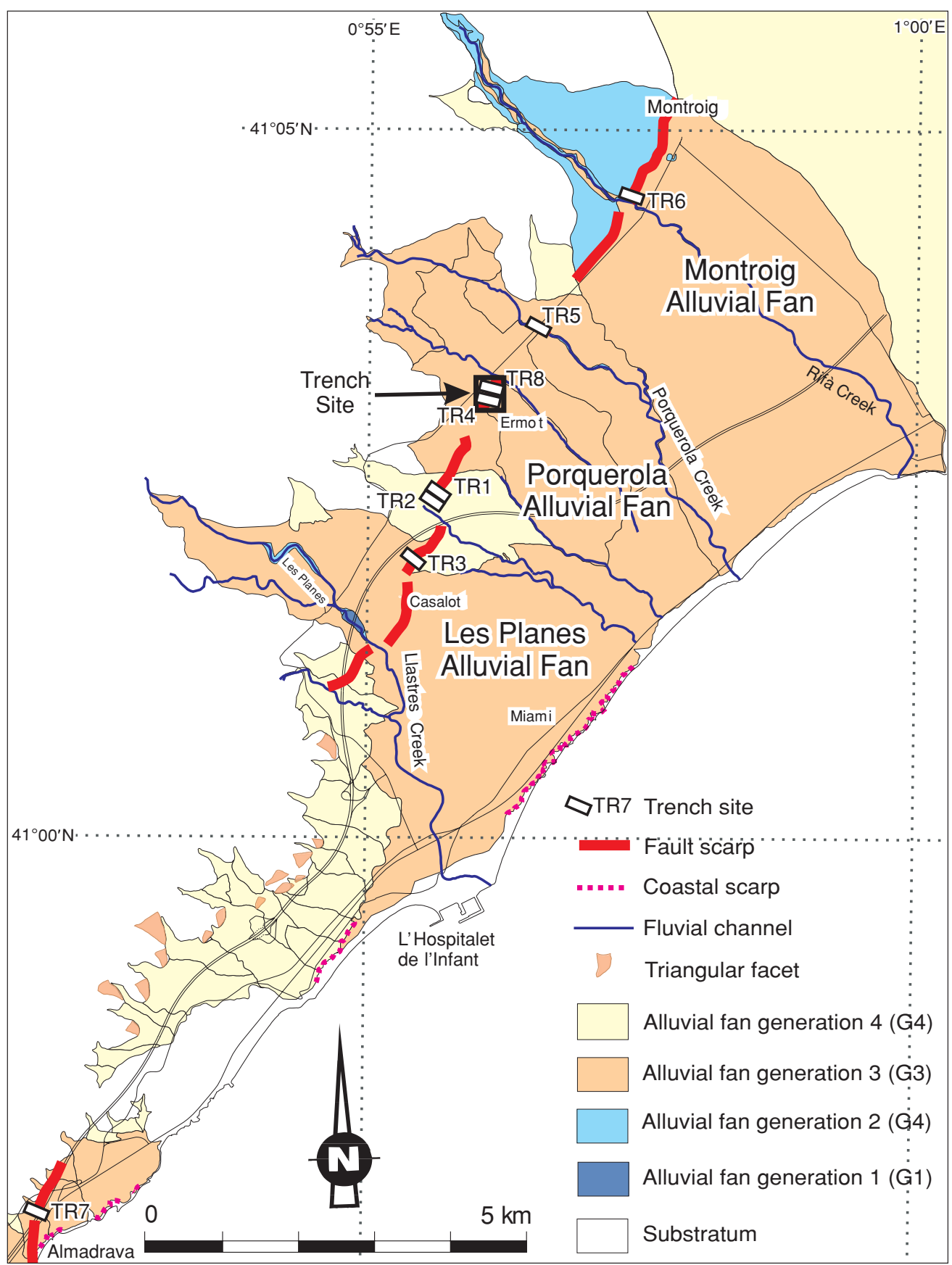

Fig. 2. The El Camp basin geomorphological map (modified from Masana et al., 2001b). Location is shown in fig. 1. The map shows the distribution of the different alluvial fan generations as well as the zones where the fault scarp intersects the different alluvial fans. 


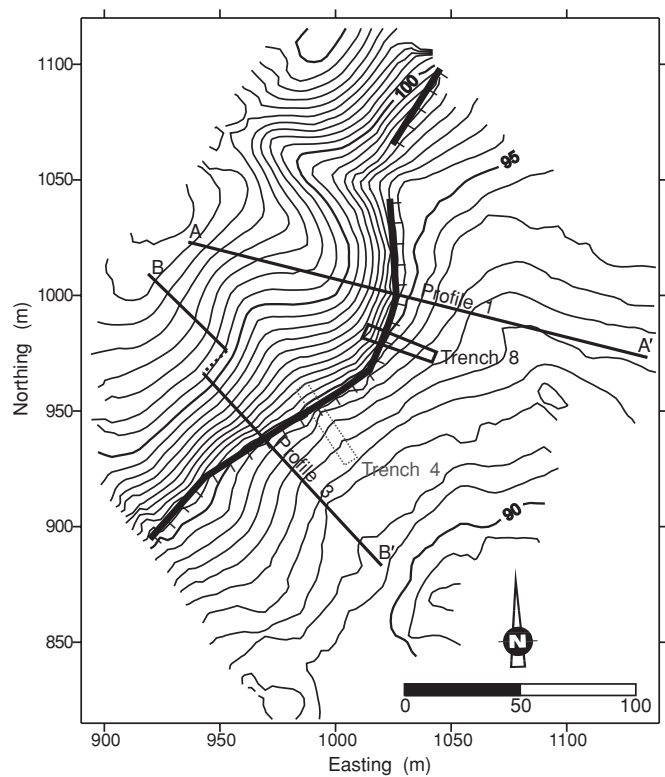

Fig. 3. Microtopographic map of the trench site. The map shows the location of trenches 8 and 4 and the long profiles 1 and 3. The fault trace is also shown. The contour line interval is $0.5 \mathrm{~m}$. et al., 2000, 2001a,b; Santanach et al., 2001), the 125000 years fan surface offset obtained by these authors in the same zone was $6.5 \mathrm{~m}$, which is more similar to the lower values obtained from our profiles. Therefore, the lower slip rate would be more realistic. On the assumption that the fault is purely normal with a dip of $60^{\circ}$ at depth, a dip slip of 0.06 to 0.09 $\mathrm{mm} / \mathrm{yr}$ is calculated.

\section{Trench analysis}

The trench dug through the scarp located at the La Porquerola fan (fig. 5) was the eighth trench dug along the El Camp Fault (Masana et al., 2000, 2001a,b; Santanach et al., 2001). The trench had a WNW-ESE orientation, a length of approximately $23 \mathrm{~m}$ and a depth of approximately $6 \mathrm{~m}$. The trench 8 logs (fig. 6) show a succession of sedimentary layers, conglomerates and gravels with different degrees of calcrete development. In the fault zone, the sediments are strongly weathered because of fluid circulation through the faults, cracks and
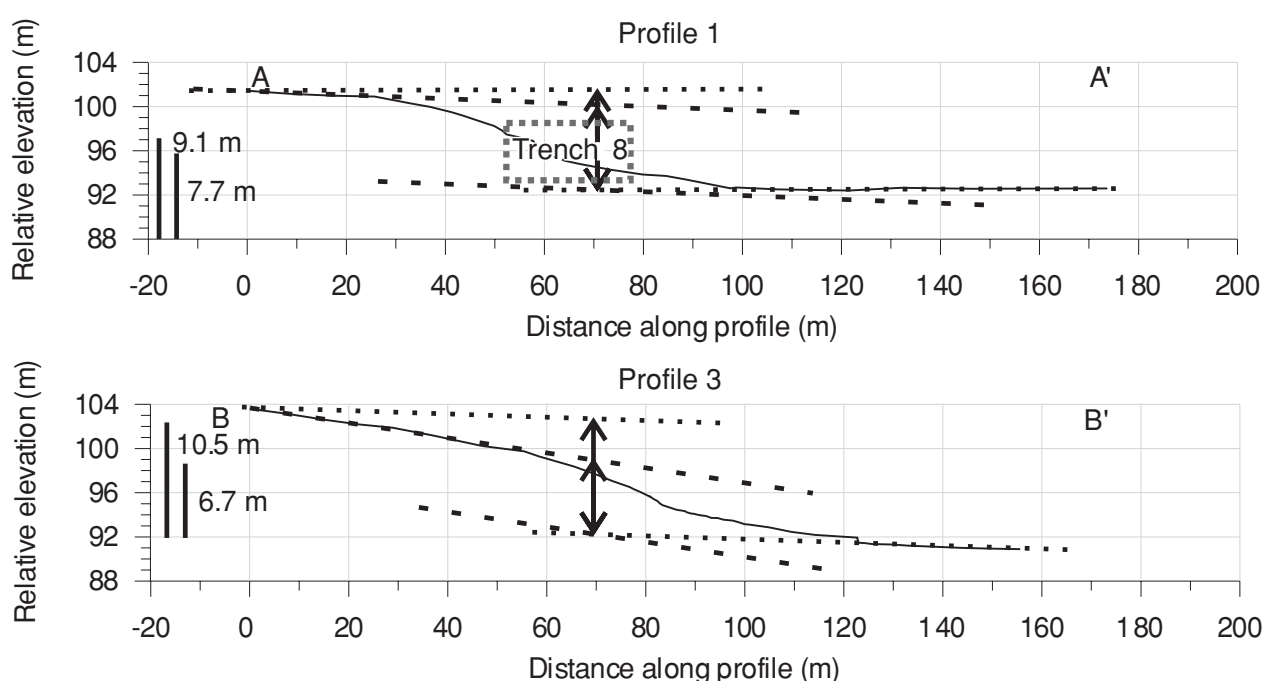

Fig. 4. Topographic profiles 1 and 3. A maximum and a minimum offset are plotted for each profile, taking into account that the original fan slope surface could correspond to the surface on the downthrown (dotted line) or upthrown block (dashed line). The position of trench 8 is projected on profile 1 . The location of the two profiles is shown in fig. 3. The vertical scale is exaggerated. 


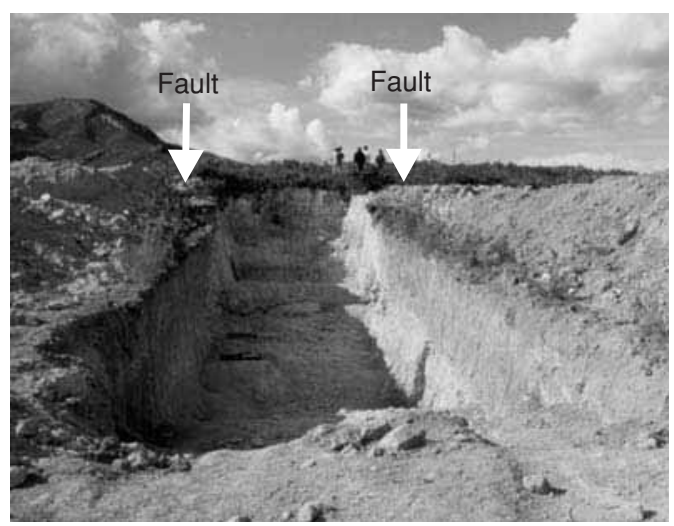

Fig. 5. Trench 8 photograph taken from the southeast. The people in the photograph are on the upthrown block of the fault.

hollows, which hinders the distinction between the different layers (fig. 7).

On the upthrown block, units B, C, D and $\mathrm{F}$ are planar and sub-parallel to each other. Only unit F, which corresponds to the top of the G3 generation alluvial fan, can be followed across the fault zone. On the downthrown block, seven units (G, H, J, K, L, L1 and M) overlie unit $\mathrm{F}$ near the scarp, but $\mathrm{F}$ appears at the surface again at a distance of approximately 40 to $50 \mathrm{~m}$ from it. Thus, units $\mathrm{G}, \mathrm{H}, \mathrm{J}, \mathrm{K}$, $\mathrm{L}, \mathrm{L} 1$ and $\mathrm{M}$ infill a local depression produced by the fault movement. The geometry of the sedimentary units on the downthrown block is more complex than on the upthrown block. Units $\mathrm{H}$ to $\mathrm{M}$ cover part of the eroded scarp produced by the faulting and bending of unit $\mathrm{F}$. The geometrical relationships between these lithological units will be discussed below in terms of paleoseismic events.

The fault zone is composed of a fault (F1) and a fracture (F2). Fault F1 is located along unit W2 and offsets units B, C, D and F. The fault plane has a subvertical attitude or dips strongly to the WNW (fig. 6). The offset top of unit F along F1 on the south wall shows a buried scarp that is $1.3 \mathrm{~m}$ high. However, this is the minimum offset since the scarp had probably been eroded. To the east of F1, frac- ture F2 has a subhorizontal dip and affects unit F. F2 is an open fracture produced by a dip slip along a normal fault (F1) and by the obstruction of the shallower part of the downthrown block of this fault (Santanach et al., 2002). This kind of movement could have produced the opening of the hollow visible at the trench along F2. The subsequent collapse of the obstructed part could have closed the hollow and could have produced a «reverse» fault geometry (fig. 8). Two minor faults are also present, F3 and F4, the former being more clearly defined than the latter. Fault F3, a small antithetic fault, affects the hard layer located at the top of unit $\mathrm{K}$ with a maximum offset of $20 \mathrm{~cm}$. F4 is defined by the $60 \mathrm{~cm}$ offset at the top of unit $\mathrm{K}$, despite being badly constrained at lower levels. Unit $\mathrm{J}$ shows a mixture of materials, and clasts with a vertical preferred orientation, which could be the result of the F4 movement.

One question we attempted to answer with the opening of the trench was whether the change in the scarp direction is due to: a) a shift in the direction of the fault, or b) to the erosion of the scarp. The analysis of the relationship between F1, the main fault, and the surface scarp, at trench 8 , shows that the change in the scarp direction is attributed to the shift in the fault direction since the scarp follows the fault direction (fig. 6). However, erosion controls the trench sedimentary architecture and could highlight the change in the scarp direction.

Eight samples were collected for radiocarbon dating. Only three of them contained sufficient material to be dated and only two (ERT8-2 and ERT8-6) provided a measured age (table I). Samples ERT8-2 (charcoal) and ERT8-6 (a shell) were collected from unit L1, ERT8-2 near the top of the unit and ERT8-6 near the limit between L1 and L. These datings indicate that unit L1 was deposited between 34000 and 13000 years BP. The other available age constraint is the age of the top of the G3 generation (Villamarín et al., 1999). Therefore, the top of unit $\mathrm{F}$ is $c a .125000$ years old and all the units exposed on the upthrown block are the same age or older with the exception of $\mathrm{M}$, which is the most recent unit. 


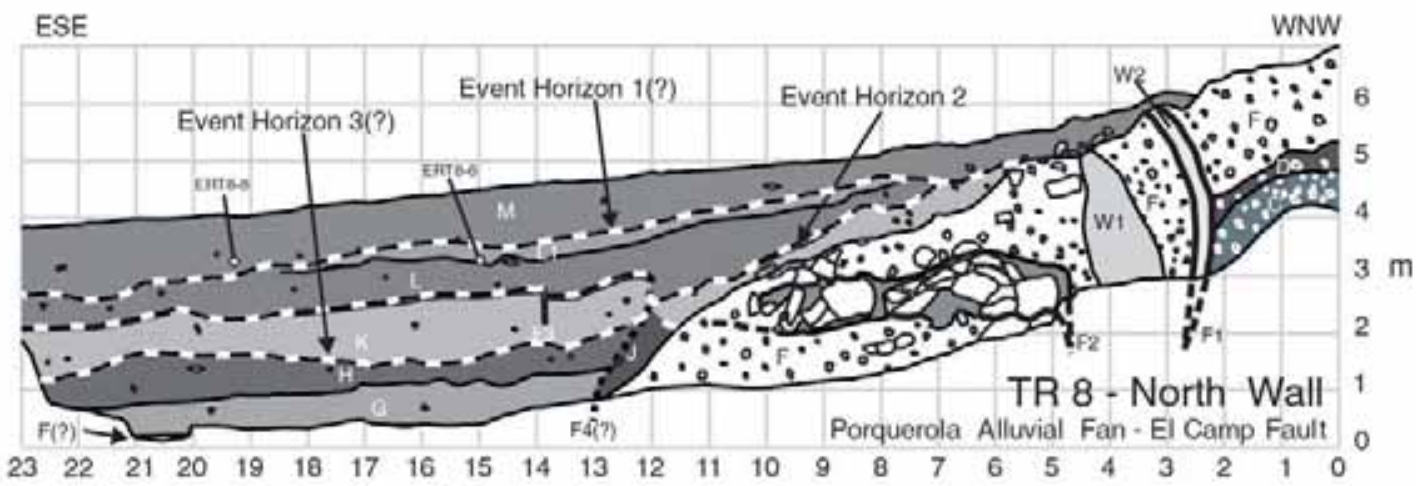

m

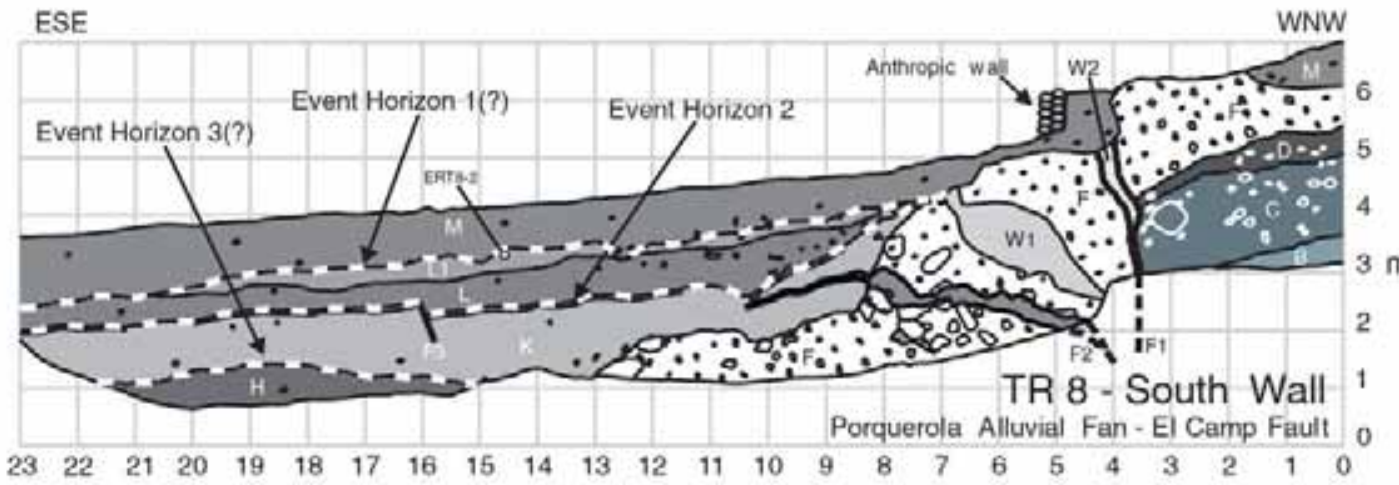

m

Unit B - Unconsolidated, well sorted sitly-clay, yellow-brown in colour, includingsome centimetre size carbonaticclasts.

C. Unit C - Strongly cemented, poorly sorted, matrix-supported conglomerate. Clasts are carbonatic, angular to subangular and range from a few centimeters to a few decimeters in size. Matrix is silty and reddish in colour.

Unit D - Poorly consolidated, well sorted, very fine sandstone reddish in colour, including some centimeter-size carbonatic clasts.

- ${ }_{F}$ Unit $\mathbf{F}$ - Strongly cemented, poorly sorted, matrix-supported conglomerate. Clasts are carbonatic, subangular to subrounded and range from a few cen-
timeters to a few decimeters in size. Matrix is silty and reddish in colour.

W1 Unit W1 - Poorly cemented and sorted, matrix-supported conglomerate. timeters to a few decimeters in size. Matrix is silty and is light-yellow in colour.

W2 Unit W2 - Poorly cemented and sorted, matrix-supported conglomerate. is silty and is pink in congur.

Unit G - Moderately consolidated, poorly sorted, matrix-supported gravel. Matrix is silty and light brown in colour.

Unit H - Poorly consolidated and sorted, matrix-supported gravel. Clasts are carbonatic, subangular to subrounded and centimetric in size. Matrix is silty-clay and brown-orange in colour.

U Unit $\mathbf{J}$ - Poorly consolidated and sorted, matrix-supported gravel. Clasts are carbonatic, subangular to subrounded and centimetric in size. Matrix is silty and brown-orange in colour.

Unit K - Poorly consolidated and sorted, matrix supported gravel. Clasts are carbonatic, subangular and range from a few centimeters to a few decimeters in size. Matrix is silty and brown in colour. At top there is a hard layer.

Unit L - Unconsolidated, poorly sorted, matrix-supported gravel. Clasts are carbonatic, subrounded and range from a few centimeters to a few decimeters. Matrix is silty and reddish-orangein colour.

Unit L1 - Unconsolidated, well sorted, fine sandstones reddish-orange in colour, including some centimeter-size carbonate clasts.

- Possible fault and fault direction

Hollow

Fig. 6. Logs of the trench 8 walls. 


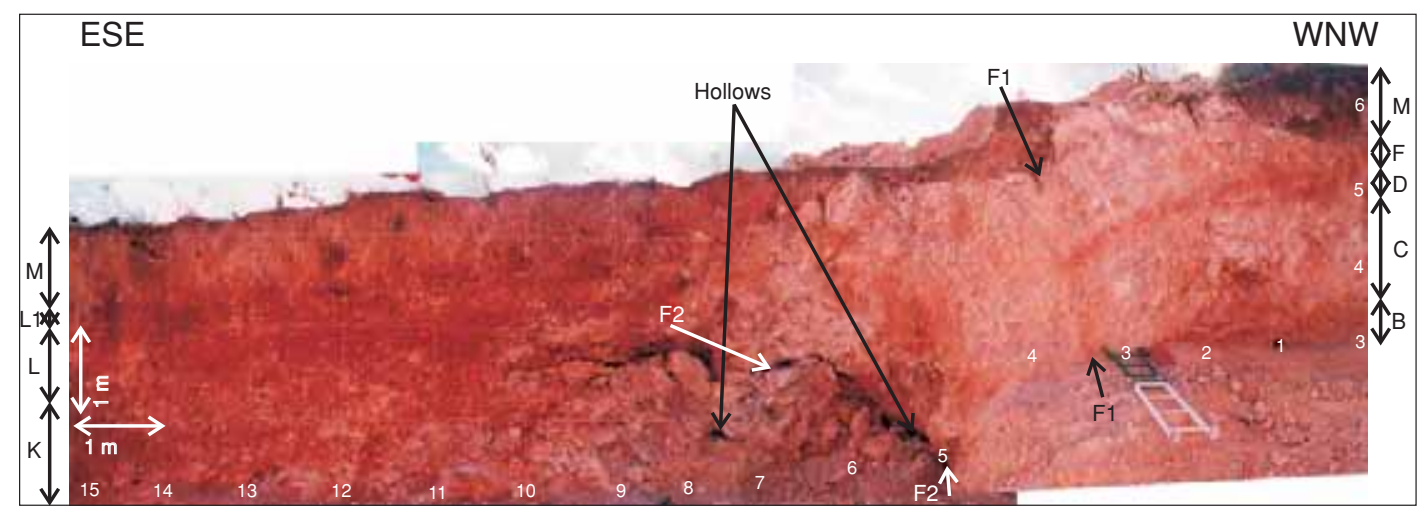

Fig. 7. Photographic assembly showing the fault zone on the south wall of trench 8 . The photograph shows the complexity of the fault zone as well as the weathering degree of the units located close to the fault. The main features and sedimentary units are shown (see the legend in fig. 6).

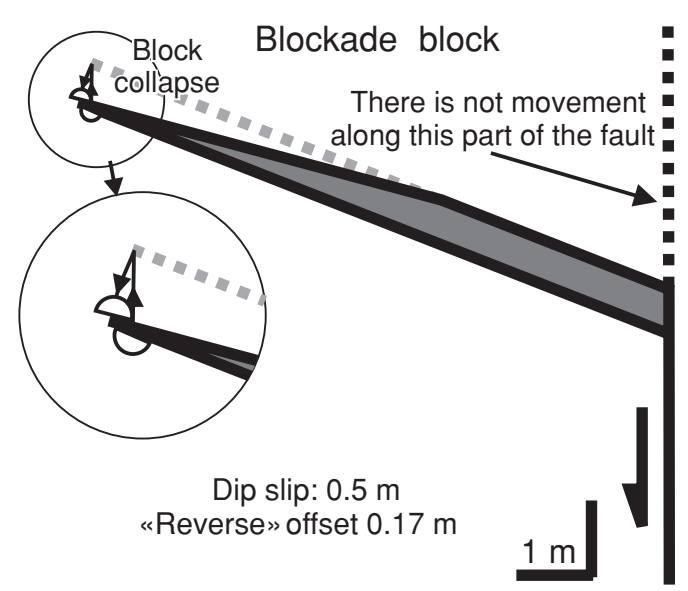

Fig. 8. This figure shows how a tensional fracture with an associated hollow and a post-collapse reverse geometry on a strongly vertical normal fault is produced (explained in the text). Semicircles identify homologue points and arrows indicate the movement of the block.

\section{Paleoseismic events}

At trench 8 we found evidence of at least one individual surface-faulting earthquake. Furthermore, evidence for two more events will be discussed. Briefly, we found evidence for three possible events (fig. 6): a) event 1 at the top of L1 (uncertain); b) event 2 at the top of K (good), and c) event 3 at the top of $\mathrm{H}$ (uncertain). We shall discuss the events beginning with the most certain event and ending with the most uncertain one. It was not possible to obtain the single event displacement at trench 8 .

Displacements along F3 (and F4?), which reach the top of unit $\mathrm{K}$, and the greater warp of this unit with respect to the overlying units suggest an event horizon, event 2, at the top of unit K. Units L and L1 represent the post event deposit.

Evidence for event 1, albeit with some uncertainty, is provided by: a) the erosional truncation of unit $\mathrm{M}$ over $\mathrm{L}$ and $\mathrm{L} 1$, and $\mathrm{b}$ ) the geometrical relations of unit $\mathrm{M}$ with respect to units L and L1. Units L and L1 filling a gentle depression appear to join the original slope, which is not consistent with the present one. Moreover, the origin of unit $\mathrm{M}$ differs from that of L and L1 in that it is much higher on the scarp. This could be explained by a change in the slope/scarp caused by a displacement along the fault (an earthquake?) and a consequent sinking of the downthrown block.

Event 3 could be located at the bottom of unit $\mathrm{K}$ based on: a) unit $\mathrm{J}$, a deformed unit, discussed above, is covered by unit $\mathrm{K}$ that shows less deformation, and $\mathrm{b}$ ) unit $\mathrm{K}$, which lies uncon- 
Table I. Trench 8 dating results.

\begin{tabular}{crcccccccc}
\hline \hline $\begin{array}{c}\text { Sample } \\
\text { name }\end{array}$ & $\delta^{13} \mathrm{C}$ & $\begin{array}{c}\text { Fraction } \\
\text { modern }\end{array}$ & \pm & $\mathrm{D}^{14} \mathrm{C}$ & \pm & ${ }^{14} \mathrm{C}$ age & \pm & $\begin{array}{c}\text { Calibrated } \\
\text { age }(*)\end{array}$ & \pm \\
\hline ERT8-2 .05 mgC & -25 & 0.2483 & 0.0076 & -751.7 & 7.6 & 11190 & 250 & $13153 \mathrm{BP}$ & 657 \\
ERT8-6 shell & 0 & 0.0143 & 0.0005 & -985.7 & 0.5 & 34130 & 280 & & \\
ERT8-8 & -25 & 1.2301 & 0.0078 & 230.1 & 7.8 & $>$ Modern & & & \\
\hline
\end{tabular}

(*) Stuiver and Reimer (1993). $\delta^{13} \mathrm{C}$ values are the assumed values according to Stuiver and Polach (1977) when given without decimal places. Values measured for the material itself are given with a single decimal place. The quoted age is in radiocarbon years using the Libby half life of 5568 years and following the conventions of Stuiver and Polach (1977). Radiocarbon concentration is given as fraction Modern, $\mathrm{D}^{14} \mathrm{C}$, and conventional radiocarbon age. Sample preparation backgrounds have been subtracted, based on measurements of samples of ${ }^{14} \mathrm{C}$-free coal for ERT8-2 and ERT8-8, and of ${ }^{14} \mathrm{C}$-free calcite for ERT8-6. Backgrounds were scaled relative to sample size. Comments: the material dated was acid-alkali-acid treated charcoal. The large uncertainty for ERT8-2 is due to the small sample size.

formably over unit $\mathrm{F}$, sealing the subhorizontal fracture and associated collapse breccia.

Given the low number of available datings, it has not been possible to determine with precision the time bracket for the three paleoseismic events. With our data, the three possible events would be younger than 125000 years BP. The oldest events ( 2 and 3 ) are older than 34000 years $\mathrm{BP}$, whereas the youngest one (event 1) would be younger than 13500 years BP.

\section{Comparison with earlier studies}

By comparing the data obtained from this new trench (trench 8) across the El Camp Fault with the paleosesimological information obtained from earlier studies on the same fault (Masana, 1995, 1996; Masana et al., 2000, 2001a,b; Santanach et al., 2001), we were able to gain a new insight into the fault behaviour.

The comparison between trenches 8 and 4 (fig. 9) shows that F1 and F2 have the same dip tendency and relative location with respect to the fault scarp at both trenches and could, therefore, be interpreted as the same faults. Accordingly, at trench 8 it is assumed that $\mathrm{F} 2$ becomes a vertical fault at a certain depth and branches into F1.

The accommodation space at trenches 4 and 8 due to the fault movement should be very similar because of their proximity, resulting in a similar sedimentary thickness. Nevertheless, the sedimentary thickness at trench 8 is greater than at trench 4 . Moreover, the top of unit $\mathrm{F}$ is approximately $2 \mathrm{~m}$ deeper at trench 8 than at trench 4 (fig. 10). This modification of the accommodation space can be attributed to a marked erosion in the vicinity of trench 8 evidenced by the small gully located to the north of it. The modification of the accommodation space should be pointed out to avoid interpreting the sedimentary relationship between units $\mathrm{F}, \mathrm{G}$ and $\mathrm{H}$ as another event.

Three seismic events have been described in relation to the El Camp Fault in the last 125000 years (Masana, 1995, 1996; Masana et al., 2000, 2001a,b; Santanach et al., 2001): a) event $X$ has a time bracket between 125000 and 50000 years $\mathrm{BP}$ and is the oldest; b) event $Y$ is between 50000 and 35000 years BP, and c) event $Z$ occurred between 25000 and 3000 years BP. At trench 8 we also found 3 events, although some uncertainty exists for events 1 and 3 . As stated above, the two oldest events at trench 8 (3 and 2) occurred in a time bracket between 125000 and 34000 years BP, whereas event 1 is younger than 13500 years BP. Therefore, events 3 and 2 could correspond to events $X$ and $Y$, respectively, and event 1 could correspond to event $Z$. Thus, trench 8 could yield evidence of the last event, which has not been recorded at trench 4 .

Although it was not possible to obtain the single displacements for events $X, Y$ and $Z$ at trench 8 , they have been reported in earlier works (Masana et al., 2000, 2001a,b; Santanach et al., 2001): a) a displacement ranging between 1.4 and 2.0 for event $X$, but the authors suggest that this displacement could correspond to the accu- 

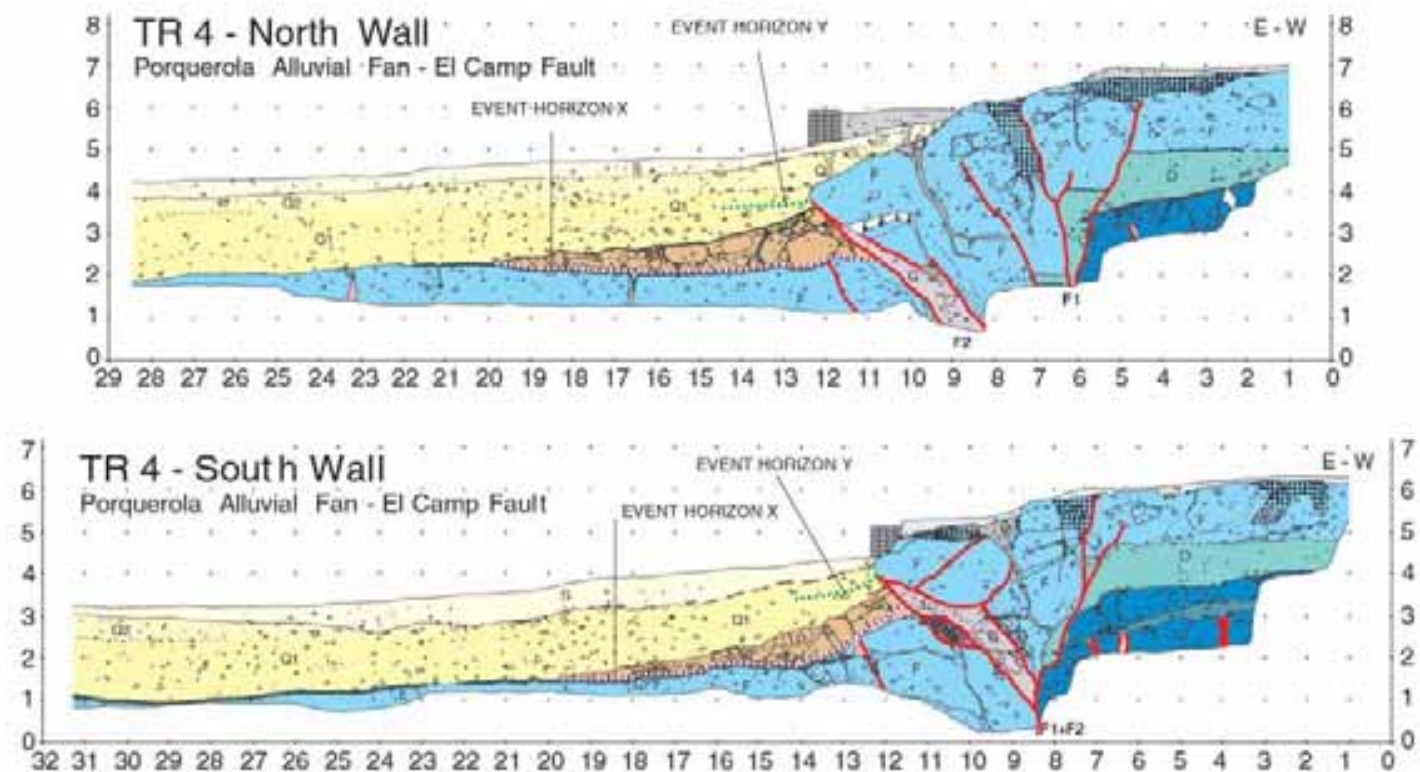
Strongly cemented, poorly selected, matrix-supported con-
glomerate. Clasts are carbonatic, subangular to subrounded, and range from a few centimeters to a few decimeters in size. Locally weathered at the top and along the joints. Laminar caliche at the top.

D Unconsolidated, well selected silt and clay light brown orange in color, including some decimeter-size, carbonatic clasts.

Highly cemented, matrix-supported conglomerate. Clasts are carbonatic, little selected, angular, and range from a few clay to silty and is pinky in color. Laminar caliche at the top. The north wall shows a clay-bed interlayered in the conglomerate. It is built up by light brown clay containing subangular clasts up to a few centimeters in size.

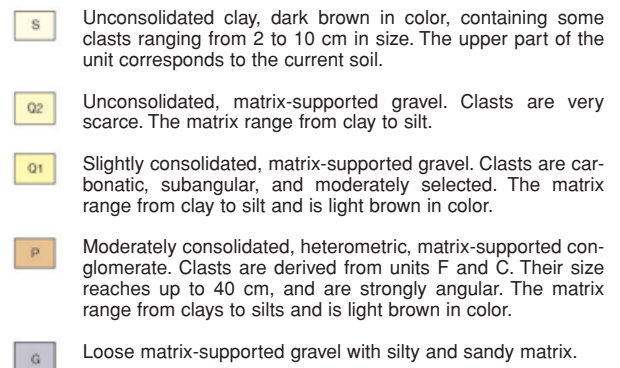

Fig. 9. Logs of trench 4 walls (modified from Masana et al., 2001b).

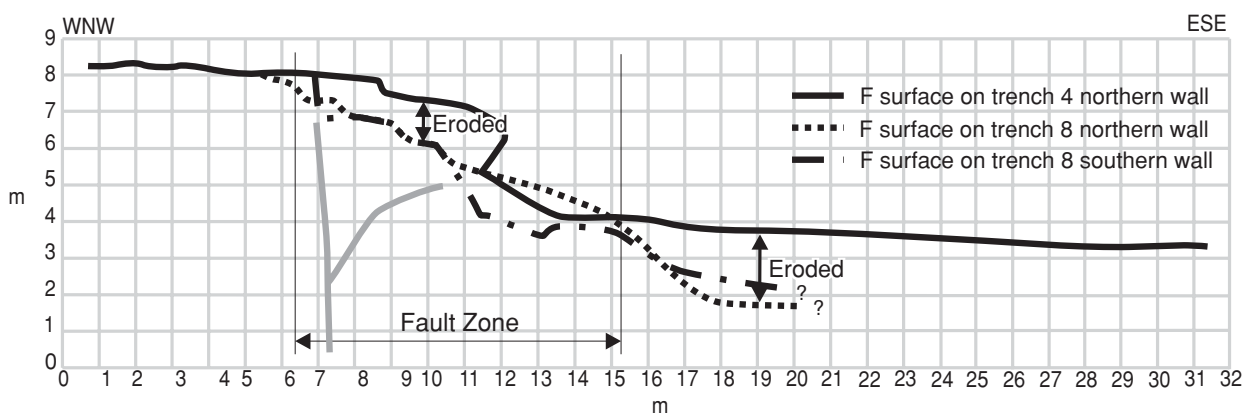

Fig. 10. The sketch shows the differences in height between the top of unit $\mathrm{F}$ on the northern wall of trench 4 and the southern and northern walls of trench 8 . The different $F$ surfaces are placed according to the F1 location and taking into account that the height of unit $F$ on the upthrown block is similar (see fig. 3). 
mulation of two events; b) $0.4 \mathrm{~m}$ of displacement for event $Y$, and c) a displacement ranging between 0.7 and $1.0 \mathrm{~m}$ for event $Z$. These displacements could correspond to a maximum earthquake with an $M_{w}$ ranging between 6.3 to 6.8 and, consequently, a rupture surface length between 13 and $24 \mathrm{~km}$ (Wells and Coppersmith, 1994), which is in agreement with the length of the El Camp Fault.

\section{Conclusions}

Two long topographic profiles made across the El Camp Fault at the La Porquerola alluvial fan allowed us to establish an offset bracket for the top of the G3 generation fan. This offset bracket ranges between 6.7 and $10.5 \mathrm{~m}$. Based on these data, the vertical slip rate for the last 125000 years ranges between 0.05 and 0.08 $\mathrm{mm} / \mathrm{yr}$ and the dip slip between 0.06 and 0.09 $\mathrm{mm} / \mathrm{yr}$. We consider the lower values to be more realistic when these are compared with the earlier studies.

The change in the scarp direction visible at the La Porquerola site is attributed to the change in the fault direction, although the erosion evidenced by the adjacent gully influenced the architecture of trench 8 .

The stratigraphic and structural analyses of the different units at trench 8 constrain one clear paleoseismic event and two less certain ones. The datings obtained give an age for the two oldest paleoseismic events (3 and 2) ranging from 125000 to 34000 years BP and an age younger than 13500 years BP for the last one (event 1). Events 1, 2 and 3 at trench 8 can be correlated with events $Z$ (3000-25 000 years BP), $Y$ (35000-50000 years BP) and $X(50000$ 100000 years BP) described in earlier studies. Event $Z$ had not been described at the La Porquerola site to date.

\section{Acknowledgements}

The data presented in this report are the result of the Europaleos course (HPCF-CT2000-00077). We wish to thank all those who attended the Europaleos course and especially
Daniela Pantosti, Pere Santanach and Eulalia Masana for organising the course. The reviews by A. Meigs and P. Villamor greatly helped to improve the manuscript.

\section{REFERENCES}

BANDA, E. and P. SANTANACH (1992): The Valencia trough (Western Mediterranean): an overview, Tectonophysics, 208, 183-202.

Doglioni, C., E. Gueguen, F. SÀbat and M. Fernández (1997): Western Mediterranean extensional basins versus Alpine orogen, Terra Nova, 9 (3), 109-112.

Doglioni, C., E. Gueguen, F. Sàbat and M. Fernández (1999): On the interference between the early ApenninesMaghrebides backarc extension and the Alps-Betics orogen in the Neogene Geodynamics of the Western Mediterranean, Boll. Soc. Geol. It., 118, 75-89.

Fontboté, J.M., J. Guimerà, E. ROCA, F. SÀbat, P. SAntAnACH and F. FERnÁndeZ-Ortigosa (1990): The Cenozoic geodynamic evolution of the València trough (Western Mediterranean), Rev. Soc. Geol. España, 3 (3/4), 249-259.

Gueguen, E., C. Doglioni and M. Fernández (1998): On the past 25 Ma geodynamic evolution of the Western Mediterranean, Tectonophysics, 298, 259-269.

MASANA, E. (1995): L'activitat neotectònica a les Cadenes Costaneres Catalanes, Doctoral Thesis, Universitat de Barcelona, pp. 444

Masana, E. (1996): Evidence for past earthquakes in an area of low historical seismicity: the Catalan Coastal Ranges, NE Spain, Ann. Geofis., 39 (3), 689-704.

Masana, E., J.A. Villamarín, J. Sanchez Cabañero, J. Plaza and P. SANTANACH (2000): Seismological behaviour of a fault with no historical seismicity: El Camp Fault (Northeastern Iberian Peninsula), in Evaluation of the Potential for Large Earthquakes in Regions of Present Day Low Seismic Activity in Europe, Workshop 13-17 March 2000 Han-Sur-Lesse, Belgium, 101-104.

Masana, E., J.A. Villamarín, J. Sánchez Cabañero, J. PLAZA and P. SANTANACH (2001a): A seismogenic fault in a low seismic area, Geol. Mijnbouw/Netherlands $J$. Geosc., 80 (3/4), 229-241.

Masana, E., J.A. Villamarín and P. Santanach (2001b): Paleoseismic results from multiple trenching analysis along a silent fault: the El Camp Fault (Tarragona, Northeastern Iberian Peninsula), Acta Geol. Hipánica, 36 (3/4), 329-354.

Mauffret, A., J.P. Fail, L. Montadert, J. Sancho and E. WinNOCK (1973): Northwestern Mediterranean sedimentary basin from seismic reflection profile, $A m$. Assoc. Petrol. Geol. Bull., 57, 2245-2262.

Medialdea, J., A. Maldonado, B. Alonso, J.L. Díaz, M. FArrán, S. Giró, A. VÁzouez, E. SAInZ-Amor, A. Martínez and T. MEdialdeA (1986): Mapa Geológico de la Plataforma Continental Española y Zonas Adyacentes, Escala 1:200000, Hoja 41/42 (TortosaTarragona), mem. expl. (IGME, Madrid), pp. 78.

Nuñez, A., I. Colodrón, V. Ruiz, I. Cabañas, A. Uralde, F. Abellán, R. Bretones and S.A. Fina IbÉrica 
(1980): Mapa Geológico de España, Escala 1:50000, Hoja 472 (Reus) (IGME, Madrid), Primera edición, pp. 33.

RocA, E. (1992): L'estructura de la Conca Catalano-Balear: paper de la compressió i de la distensió en la seva gènesi, Doctoral Thesis, Universitat de Barcelona, pp. 330 .

RocA, E. (1996): La evolución geodinámica de la Cuenca Catalano-Balear y áreas adyacentes desde el Mesozoico hasta la actualidad, Acta Geol. Hipánica, 29 (1), 3-25.

RocA, E. and J. GUIMERÀ (1992): The Neogene structure of the eastern Iberian margin: structural constrains on the crustal evolution of the València trough (Western Mediterranean), Tectonophysics, 203, 203-218.

SÀbat, F., E. Roca, J.A. MuÑoz, J. Vergés, P. SANTANACH, M. Sans, E. Masana, A. Estévez and C. Santisteban (1997): Role of extension and compression in the evolution of the eastern margin of the Iberia: the ESCIValència trough seismic profile, Rev. Soc. Geol. España, 8 (4), 431-448.

Santanach, P., E. Masana, J.A. Villamarín, J. SAncheZ
Cabañero and J. Plaza (2001): Proyecto Datación, Publicaciones CSN, pp. 159.

Santanach, P., E. Masana and H. Perea (2002): Structure of the Montroig scarp (El Camp Fault, NE Iberian Peninsula): paleoseismological implications, in XXVIII General Assembly of the European Seismological Commission (ESC), 1-6 September 2002, Genoa, Italy, Book of Abstracts (University of Genoa), pp. 204.

Stuiver, M. and H. PolaCh (1977): Discussion: reporting of C-14 data, Radiocarbon, 19 (3), 355-363.

Stuiver, M. and P.J. ReIMER (1993): Extended (super 14) C data base and revised CALIB 3.0 (super 14) C age calibration program, Radiocarbon, 35 (1), 215-230.

Villamarín, J.A., E. Masana, T. Calderón, R. Julià and P. SAntanach (1999): Abanicos aluviales cuaternarios del Baix Camp (provincia de Tarragona): resultados de dataciones radiométricas, Geogaceta, 25, 211-214.

Wells, D.L. and K.J. CopPersmith (1994): New empirical relationships among magnitude, rupture length, rupture width, rupture area, and surface displacement, Bull. Seismol. Soc. Am., 84, 1-24. 